\title{
The natural course of gold nephropathy: long term study of 21 patients
}

\author{
C L HALL， N J FOTHERGILL， M M BLACKWELL， P R HARRISON， J C MACKENZIE, \\ A G MACIVER
}

\begin{abstract}
To clarify the natural course of gold nephropathy and thereby facilitate its clinical management 21 patients with rheumatoid arthritis who developed proteinuria during treatment with intramuscular sodium aurothiomalate were studied in detail throughout their renal illnesses. Renal biopsies were performed, and creatinine clearance and proteinuria were measured serially for 60 months (range 16-130 months). Ten patients developed proteinuria after six months' treatment, 15 after 12 months, and 18 after 24 months. When treatment was stopped the proteinuria reached a median peak of 2.1 g/day (range 0.7-30.7 g/day) at two months (range 1-13 months) before resolving spontaneously, in eight patients by six months, in 13 by 12 months, and in 18 by 24 months. All patients were free of proteinuria by 39 months, the median duration being 11 months. The median first and last - measurements of creatinine clearance showed no significant change (77 $\mathrm{ml} / \mathrm{minute}$ and $59 \mathrm{ml} / \mathrm{minute}$, respectively), and no patient died from or needed treatment for renal failure. HLA-B8 or DR3 alloantigens, or both, were identified in seven patients. Renal biopsy specimens showed membranous glomerulonephritis in 15 patients, a minimal change nephropathy in two, mesangial electron dense deposits in two, and no appreciable glomerular changes in two.
\end{abstract}

In these 21 patients the proteinuria of gold nephropathy

Department of Renal Medicine, Royal United Hospital, Bath C L HALL, MD, MRCP, consultant physician and nephrologist N J FOTHERGILL, MRCP, senior house officer in medicine M M BLACKWELL, MRCP, senior house officer in medicine

Renal Unit, Southmead Hoopital, Bristol

PR HARRISON, MRCP, consultant nephrologist J C MACKENZIE, FRCP, consultant nephrologist

Department of Patholosy, Southmead Hospital A G MACIVER, FRCPATH, consultant pathologist

Correspondence to: Dr Hall. resolved completely when treatment was withdrawn. Renal function did not deteriorate, corticosteroids were unnecessary, and several different renal lesions were seen.

\section{Introduction}

Gold has been accepted as an effective second line treatment for rheumatoid arthritis, but complications are common and include renal damage in $2-10 \%$ of patients. This presents as proteinuria of widely varying severity $(0 \cdot 4-39.0 \mathrm{~g} /$ day) and causes otherwise successful treatment to be stopped. ${ }^{1}$ Gold nephropathy has been observed at all ages (2-73 years) and with all gold preparations, whether given parenterally or orally. ${ }^{2}$ It may develop at any time from two weeks (total dose $10 \mathrm{mg}$ ) to six years $(6000 \mathrm{mg}$ ) after the start of treatment ${ }^{36}$ and occurs particularly in patients with seronegative rheumatoid arthritis. ${ }^{467}$ The proteinuria resolves spontaneously in some patients when the gold is stopped, ${ }^{68-10}$ but the time course is not known; in other patients it persists ${ }^{11}$ or responds only to high doses of corticosteroids. ${ }^{368101213}$ Limited data indicate that renal function usually remains normal or is only slightly impaired ${ }^{610} 13$ although severe impairment has been reported $^{12}$ and serial and long term measurements have not been made. Recent immunogenetic and metabolic studies indicated that gold nephropathy is more likely to occur in patients with rheumatoid arthritis positive for the HLA-B8 or HLA-DR3 antigen $^{14} 15$ or who have a low capacity for the sulphoxidation of carbocisteine. ${ }^{16}$ Renal biopsy usually showed membranous glomerulonephritis ${ }^{361012} 13$ but not invariably. ${ }^{14913}$

Current knowledge of gold nephropathy is based on case reports and reports of small series of patients, none of which have contained the serial clinical data that are essential to an understanding of the natural course of the disease. We studied 21 patients with rheumatoid arthritis and gold nephropathy in detail throughout the whole of their renal illnesses to try to provide these data.

\section{Patients and methods}

Between October 1974 and August 1983, 21 patients (10 men and 11 women) with rheumatoid arthritis who had not previously had pro- 
teinuria were referred with proteinuria that had developed while they were receiving treatment with sodium aurothiomalate intramuscularly. All patients fulfilled the American Rheumatism Association's criteria for the diagnosis of rheumatoid arthritis, and in 19 circulating IgM rheumatoid factor was present. The gold had been given as a standard regimen, a $10 \mathrm{mg}$ test dose having been followed by $50 \mathrm{mg}$ at weekly intervals until a satisfactory clinical response had been achieved. Thereafter $50 \mathrm{mg}$ injections had been given at fortnightly or monthly intervals to maintain the remission.

TABLE I-Clinical details of 21 patients studied

\begin{tabular}{|c|c|c|c|}
\hline & Median & $\begin{array}{l}\text { Interquartile } \\
\text { range }\end{array}$ & $\begin{array}{l}\text { Total } \\
\text { range }\end{array}$ \\
\hline $\begin{array}{l}\text { Rheumatoid factor (IU) } \\
\text { Age at onset of rheumatoid arthritis (years) } \\
\text { Time between diagnosis of rheumatoid arthritis }\end{array}$ & $\begin{array}{r}384 \\
49\end{array}$ & $\begin{array}{c}112-1024 \\
40-57\end{array}$ & $\begin{array}{l}32-4096 \\
28-67\end{array}$ \\
\hline $\begin{array}{l}\text { and start of gold treatment (months) } \\
\text { Time between start of gold treatment and onset of }\end{array}$ & 42 & $11-81 \cdot 5$ & $5-342$ \\
\hline $\begin{array}{l}\text { proteinuria (months) } \\
\text { Total dose of gold received (mg) }\end{array}$ & $\begin{array}{r}7 \\
930\end{array}$ & $\begin{array}{c}4-17 \cdot 5 \\
693-1895\end{array}$ & $\begin{array}{l}0 \cdot 5-39 \\
40-5265\end{array}$ \\
\hline
\end{tabular}

TABLE II-Time of onset of proteinuria during treatment with gold

\begin{tabular}{|c|c|c|c|c|}
\hline $\begin{array}{l}\text { Months of } \\
\text { treatment }\end{array}$ & $\begin{array}{l}\text { No of patients } \\
\text { developing proteinuria }\end{array}$ & $\begin{array}{l}\% \text { Of } \\
\text { total }\end{array}$ & $\underset{\%}{\text { Cumulative }}$ & $\begin{array}{c}\text { Mean dose } \\
\text { (mg) }\end{array}$ \\
\hline $\begin{array}{l}1 \\
2 \\
3\end{array}$ & $\left.\begin{array}{l}1 \\
1 \\
0\end{array}\right\}$ & 9.5 & 9.5 & 363 \\
\hline $\begin{array}{l}4 \\
5 \\
6\end{array}$ & $\left.\begin{array}{l}4 \\
2 \\
2\end{array}\right\}$ & $38 \cdot 1$ & $47 \cdot 6$ & 695 \\
\hline $\begin{array}{l}7 \\
8 \\
9\end{array}$ & $\left.\begin{array}{l}1 \\
1 \\
1\end{array}\right\}$ & $14 \cdot 3$ & 61.9 & 1060 \\
\hline $\begin{array}{l}10 \\
11 \\
12\end{array}$ & $\left.\begin{array}{l}0 \\
1 \\
1\end{array}\right\}$ & 9.5 & $71 \cdot 4$ & 1518 \\
\hline $\begin{array}{l}17 \\
18\end{array}$ & $\left.\begin{array}{l}1 \\
1\end{array}\right\}$ & $9 \cdot 5$ & $81 \cdot 0$ & 1535 \\
\hline 23 & 1 & $4 \cdot 8$ & $85 \cdot 7$ & 2370 \\
\hline 31 & 1 & $4 \cdot 8$ & 90.5 & 3035 \\
\hline 39 & 2 & 9.5 & $100 \cdot 0$ & 5262 \\
\hline
\end{tabular}

\section{Results}

Table I shows details of the patients and their treatment. The renal biopsies were performed three months (interquartile range 1-6, range $0 \cdot 1-16 \cdot 0$ months) after the treatment had been stopped.

\section{PROTEINURIA}

Table II shows the time of onset of proteinuria (between two weeks and 39 months) after the start of treatment with gold. The peak incidence occurred between four and six months of treatment, when eight patients presented. Overall, 10, 15, and 18 patients had presented by six, 12, and 24 months, respectively.

The severity of the proteinuria varied greatly $(0 \cdot 7-30 \cdot 7 \mathrm{~g} /$ day $)$ and was not associated with the duration of treatment or the total dose of gold received. Table III shows the median initial and maximum measurements of proteinuria. In 10 patients the initial measurement was also the maximum, while in 11 the proteinuria increased for four months (interquartile range 3-11, range 1-13 months) after treatment was stopped. In eight patients the proteinuria was within the range indicating the nephrotic syndrome (median 5.3 g/day; interquartile range 3.6-15.6, range 3.6-30.7 g/day) and persisted for a median period of 4.5 months (interquartile range 2-11, range 2-18 months). In all cases the nephrotic syndrome was controlled with a diet high in protein and low in salt and by treatment with diuretics. Proteinuria persisted for 29,30 , and 39 months, respectively, in three patients, though was less severe. The median duration of proteinuria was 11 months (interquartile range 4-19, range 1-39 months), and in al 21 patients it resolved completely and did not recur. At six, 12, and 24 months after gold treatment was stopped the proteinuria had resolved in eight, 13, and 18 patients, respectively, and all were free by 39 months (fig 1).

\section{RENAL FUNCTION}

The median initial and last measurements of creatinine clearance in all 21 patients were $77 \mathrm{ml} / \mathrm{min}$ (interquartile range $60-108$, range $18-185 \mathrm{ml} / \mathrm{min}$ ) and $59 \mathrm{ml} / \mathrm{min}$ (interquartile range 42-86, range 33-134 $\mathrm{ml} / \mathrm{min}$ ). with an interval of 60 months (interquartile range 39-85, range 16-130 months); the deterioration was not significant. Figure 2 shows the creatinine clearances measured in the first and second six months and within two year'periods thereafter. Only three patients had initial creatinine clearances of less than $50 \mathrm{ml} / \mathrm{min}(18,41$, and $44 \mathrm{ml} / \mathrm{min})$; and all improved during the follow up period (33, 50, and $48 \mathrm{ml} / \mathrm{min}$, respectively). No patient died from or needed treatment for chronic renal failure.

TABLE III-Initial and maximum measurements of proteinuria

\begin{tabular}{|c|c|c|c|c|c|c|c|}
\hline \multirow[t]{2}{*}{ ? } & \multirow{2}{*}{$\begin{array}{c}\text { No } \\
\text { of } \\
\text { patients }\end{array}$} & \multicolumn{3}{|c|}{ Proteinuria (g/day) } & \multicolumn{3}{|c|}{ Time:(months) } \\
\hline & & Median & Interquartile range & Range & Median & Interquartile range & Range \\
\hline $\begin{array}{l}\text { Initial } \\
\text { Maximum (after treatment with gold stopped) }\end{array}$ & $\begin{array}{l}21 \\
21\end{array}$ & $\begin{array}{l}1 \cdot 7 \\
2 \cdot 1\end{array}$ & $\begin{array}{l}0 \cdot 9-3 \cdot 1 \\
1 \cdot 1-4 \cdot 1\end{array}$ & $\begin{array}{l}0 \cdot 6-6 \cdot 4 \\
0 \cdot 7-30 \cdot 7\end{array}$ & औ & $\stackrel{1}{1-6}$ & $\stackrel{\star}{\star}$ \\
\hline
\end{tabular}

^Not applicable.

Before each injection of gold the urine was tested for protein (Labstix; Ames). When appreciable proteinuria was detected $(>0.3 \mathrm{~g} / \mathrm{l})$ the gold was stopped and 24 hour urinary protein excretion and creatinine clearance were measured. Intravenous urography and percutaneous renal biopsy were carried out on all patients, and the tissue obtained was processed by conventional methods and examined by light microscopy, immunofluorescence, and electron microscopy. Causes of proteinuria other than gold nephropathy, including amyloid, vasculitis, systemic lupus erythematosus, and analgesic nephropathy, were excluded by histological examination of the renal biopsy specimen, appropriate immunological tests (antinuclear factor and deoxyribonucleic acid binding), and intravenous urography. Each patient was followed up at intervals of one to three months until the proteinuria had resolved and at intervals of one to two years thereafter, when 24 hour creatinine clearance and proteinuria were measured.

The results of the study are presented as the median value, interquartile range (defined by the 25th and 75th centiles), and total range to indicate the wide dispersion and non-parametric distribution of the data; statistical analysis was performed with the Mann-Whitney $U$ test.

\section{HLA TYPING}

Tissue typing was performed in 11 patients. The HLA-B8 alloantigen was detected in five, DR3 in four, and DR4 in four. Overall, seven of the 11 patients were positive for HLA-B8 or DR3, or both.

\section{RENAL ULTRASTRUCTURE}

Adequate renal biopsy specimens were obtained from all patients. In 15 ultrastructural changes characteristic of membranous glomerulonephritis were present in the capillary loops, with subepithelial electron dense deposits seen on electron microscopy and granular deposits of IgG and complement on immunofluorescence. On light microscopy, however, epimembranous "spikes" were seen in only four specimens and the most common abnormality (present in 13 of the 15 specimens) was an increase in the number of mesangial cells and the extent of the matrix. The specimens from the remaining six patients all showed an increase in the number of 


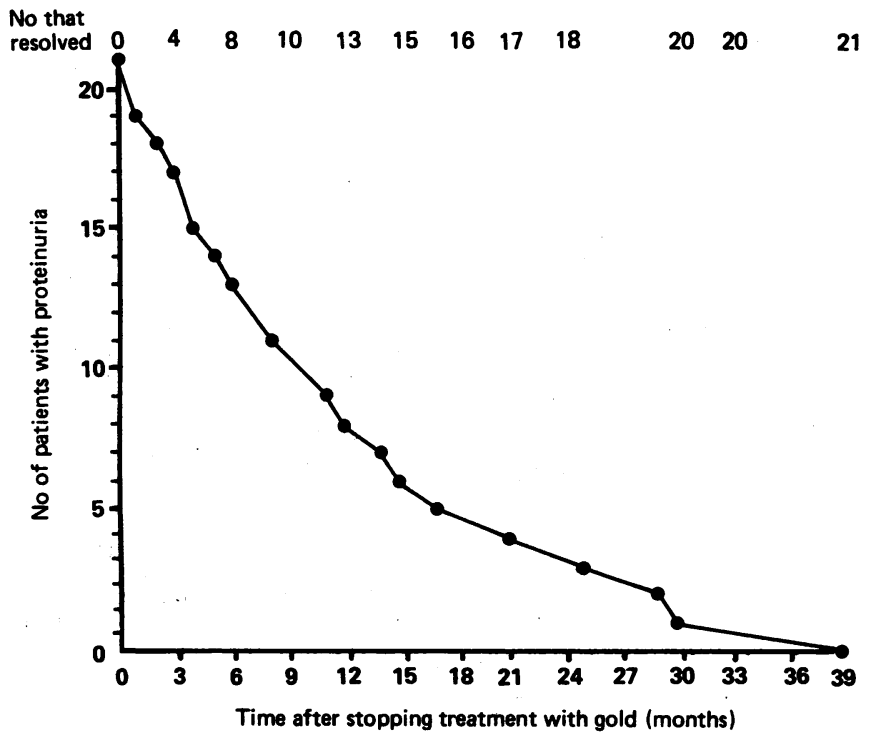

FIG 1-Time to resolution of proteinuria after treatment with gold stopped.

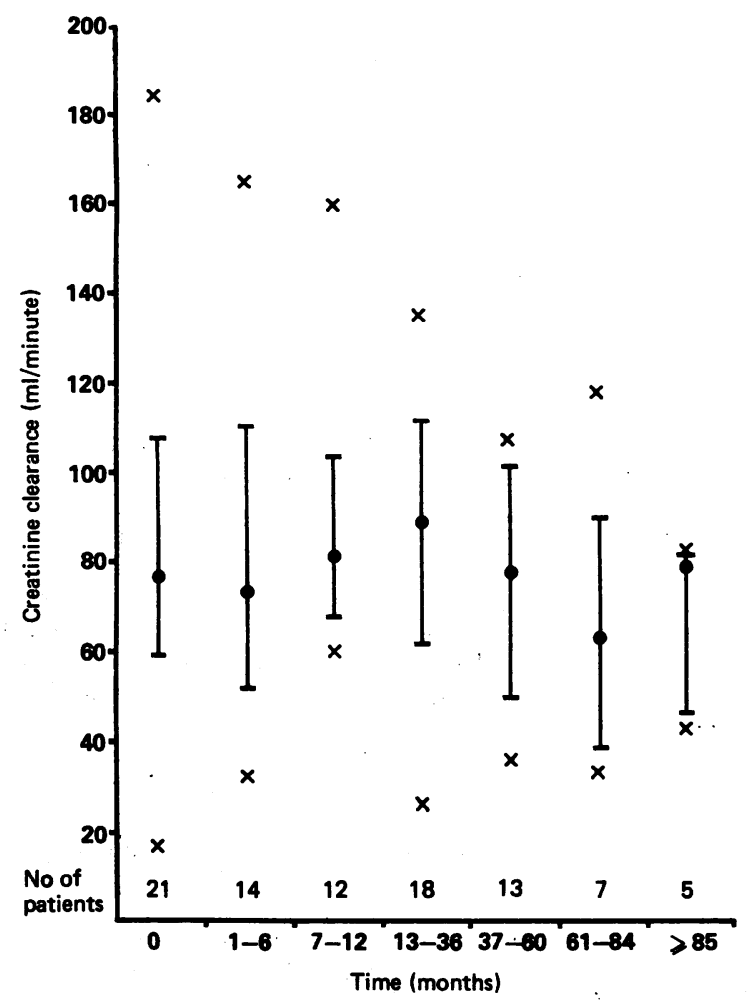

FIG 2-Serial measurements of creatinine clearance after treatment with gold stopped. Values are given as median $(O)$ and interquartile range (vertical bars) and total range $(x)$.

mesangial cells and the extent of the matrix on light microscopy and yielded negative results when tested for immunoglobulins and complement with immunofluorescence. Electron microscopy showed extensive fusion of epithelial cell foot processes in two biopsy specimens, which, in the absence of other appreciable changes, was compatible with a minimal change nephropathy. In a further two biopsy specimens mesangial electron dense deposits indicative of a mesangial glomerulonephritis were seen, and in the final two specimens no glomerular abnormalities were detected.

\section{Discussion}

This long term study of gold nephropathy has identified the clinical features that make up its natural course. Gold nephropathy occurs in patients with rheumatoid arthritis of all ages and both sexes. The suggestion that it occurs predominantly in patients who are seronegative ${ }^{47}$ is not supported by the present data or by previous reports. ${ }^{511-13}$ Though confirming that proteinuria may develop at any time during treatment with gold, ${ }^{1}$ our study showed that the peak incidence occurred between four and six months after the start of treatment, when $38 \%$ of all cases had presented, and that $71 \%$ presented within the first year. No clinical variables have been found that predict the development of gold nephropathy. ${ }^{1}$ The association with the HLA alloantigens B8 and DR3 is only partial, and tissue typing is too complex and expensive for routine use. ${ }^{14}$ is Recently, Madhok et al observed that adverse reactions to sodium aurothiomalate, including proteinuria, occurred more commonly in patients with rheumatoid arthritis who had a low sulphoxidation capacity for carbocisteine. ${ }^{16}$ This test requires prospective evaluation to determine its usefulness in routine clinical practice. Currently regular analysis of urine with a reagent stick during treatment with gold remains the best clinical test for detecting gold nephropathy.

We have confirmed previous reports that the severity and duration of the proteinuria vary greatly, ${ }^{369-11}$ and there was no correlation with the duration of treatment or the total dose received. ${ }^{3}$ In all cases the proteinuria resolved completely after treatment was stopped: though it usually resolved within two years, it occasionally increased for up to 13 months and persisted for 39 months. These data indicate that previous reports of apparently irreversible proteinuria ${ }^{361013}$ were premature as the follow up period did not exceed 26 months in any series.

The creatinine clearance measurements reported in this study are the first long term serial measurements of renal function in gold nephropathy and indicate that significant deterioration did not occur. Even when renal function was severely impaired at presentation improvement occurred and was maintained when treatment with gold was stopped.

These results show clearly that in patients with proteinuria treatment with gold should be stopped and renal function and proteinuria monitored at intervals of one to three months until the proteinuria has resolved. The nephrotic syndrome that develops in one third of those affected can be controlled with a diet high in protein and low in salt and by treatment with diuretics. Treatment with high doses of corticosteroids, which has been used previously, ${ }^{36101113}$ is not indicated as it is unnecessary and potentially hazardous, and there is no evidence that it shortens the duration of the proteinuria or leads to a more rapid or more complete resolution of the renal lesion. Referral for renal biopsy is necessary only if proteinuria within the range indicating the nephrotic syndrome ( $>3 \mathrm{~g} /$ day) persists for more than one year, if less severe proteinuria persists for more than three years, if renal function deteriorates appreciably, or if there is concern that a second disease (usually amyloid) may be present.

Membranous glomerulonephritis is the renal lesion most commonly associated with gold treatment ${ }^{3612}$ and was seen in 15 patients $(71 \%)$ in the present series. In two of the six patients who did not have this lesion the renal biopsy specimen showed a minimal change nephropathy, which has been reported previously in association with treatment with gold..$^{49} 10$ In a further two patients the presence of mesangial electron dense deposits indicated that a mesangial lesion was the cause of the proteinuria. The remaining two patients who had normal glomeruli on immunofluorescence and electron microscopy both had only low grade proteinuria $(<1 \mathrm{~g} /$ day), which may have been of tubular rather than glomerular origin.

Thus it seems that gold nephropathy encompasses several types of renal damage due to different pathogenetic mechanisms. In patients with rheumatoid arthritis not receiving gold (or penicillamine) there is an increased incidence of both membranous glomerulonephritis ${ }^{1317}$ and mesangial changes ${ }^{1411}$ due to deposition of immune complexes in specific regions of the glomerulus. Treatment with gold may modify the immune system, thereby aggravating the persistence and deposition of existing "rheumatoid" immune complexes, causing an increased incidence of membranous glomerulonephritis, and potentiating the mesangial lesions of the 
rheumatoid arthritis. It may intensify the glomerular injury mediated by $\mathrm{T}$ cells, leading to a minimal change nephropathy, and by a direct nephrotoxic action cause tubular proteinuria and release the renal tubuloepithelial antigen that may be of particular importance in the immunopathogenesis of membranous glomerulonephritis. ${ }^{17}$ Thus treatment with gold may cause renal damage by mechanisms that are not a primary part of rheumatoid disease as well as by potentiating existing immune abnormalities.

Although these data were from patients receiving parenteral sodium aurothiomalate, they may also be relevant to patients with renal damage caused by any gold preparation, parenteral or oral. ${ }^{12}$ As treatment with gold is effective and widely used for active and progressive rheumatoid disease gold nephropathy will continue to occur and a detailed knowledge of the natural course of the condition is essential for the correct management of affected patients.

We thank Mr Brian Amer for technical help and Dr P Klouda, department of immunogenetics, Southmead Hospital, who performed the tissue typing.

\section{References}

1 Hall CL. Gold and D-penicillamine induced renal glomerular disease. In: Bacon PA, Hadler NM, eds. The kidney in rheumatic disease. London: Butterworths, 1982:246-66.
2 Katz WA, Blodgett RC, Pietruska RG. Proteinuria in gold treated rheumatoid arthritis. Ann Intern Med 1984;101:176-9.

3 Silverberg DS, Kidd EG, Shnitka TH, Ulan RA.Gold nephropathy: a clinical and pathological study. Arthritis Rhewm 1970;13:812-25.

4 Tornmoth TS, Skrifvars B. Gold nephropathy: prototype of membranous glomerulonephritis. Am f Pathol 1974;75:573-84.

5 Davies DT, Dowling J, Xipell J. Gold nephropathy. Patholozy 1977;9:281-8.

6 Skrifvars B, Tornroth TS, Tallquist GN. Gold induced immune complex nephritis in seronegative rheumatoid arthritis. Amn Rherem Dis 1977;36:549-56.

7 Skrifvars B. Hypothesis for the pathogenesis of sodium aurothiomalate induced immune complex nephritis. Scand I Rheumatol 1979;8:113-8.

8 Strunk SW, Ziff M. Ultrastructural studies of the passage of gold thiomalate across the renal glomerular capillary wall. Arthritis Rheum 1970;13:39-52.

9 Watanabe I, Whittier FC Jr, Moore J, Cuppage FE. Gold nephropathy. Ultrastructural, fluorescence, and microanalytic studies of two patients. Arch Pathol Lab Med 1976;100:632-5.

10 Viol GW, Minielly TA, Bistricki T. Gold nephropathy tissue analysis by $x$-ray fluorescent spectroscopy. Arch Pathol Lab Med 1977;101:635-40.

11 Lee TC, Dushkin J, Eyring EJ, Engelman EP, Hopper J. Renal lesions associated with gold therapy: light and electron microscopic studies. Arthritis Rheum 1965;8:1-13.

12 Burger HR, Briner J, Spycher MA. Auffallige Häufung membranöser Glomerulonephritiden narger HR, Briner J, Spycher MA. Auffallige Häufung membranöser Glomerulonephritiden
nach Goldtherapie bei chronischer Polyarthritis-eine Nebenwirkung eines neuen Präparates? nach Goldtherapie bei chronischer Polyarth
Schweiz Med Wochenschr 1979;109:423-31.

13 Samuels B, Lee JC, Engelman EP, Hopper J. Membranous nephropathy in patients with rheumatoid arthritis: relationship to gold therapy. Medicine 1977;57:319-27.

14 Wooley PA, Griffin J, Panayi GS, Batchelor JR, Welsh KJ, Gibson TJ. HLA-DR antigens and toxic reactions to sodium aurothiomalate and D-penicillamine in patients with rheumatoid arthritis. N Engl F Med 1980;303:300-2.

15 Speerstra R, Reekers P, van der Putte LB, van den Brouche JR, Rasker JJ, de Rooi DJ. HLA-DR antigens and proteinuria induced by aurothioglucose and D-penicillamine in patients with theumatoid arthritis. I R heremaral 1983;10:448-53.

16 Madhok R, Cappell HA, Waring R. Does sulphoxidation state predict gold toxicity in rheumatoid arthritis? Br Med F 1987;294:483.

17 Honkanen E, Tornroth T, Petterson E, Skrifvars B. Membranous glomerulonephritis in rheumatoid arthritis not related to gold or D-penicillamine therapy. Clin Nephrol 1987;27:87-93.

(Accepted 4 August 1987)

ONE HUNDRED YEARS AGO

Since the publication of our article on the above subject on Saturday last, we have been at pains to obtain the best information on the point at issue, from officers of standing and experience in the combatant as well as in the departmental ranks of the army. Far from having any reason to believe that the note of alarm we sounded was false, we are satisfied that it was not an hour too soon to call attention to what we are constrained to believe was an intended blow at the status of our professional brethren in the army. The medical staff do not need any exposition of the case at our hands; they have to wear the shoe, and they know where it pinches. It is to the profession in civil life that we address our remarks to-day, more particularly to men of light and leading in our ranks, to the professors and teachers in our universities and medical schools in the great centres of education throughout the kingdom, and to the young men whose professional education is sufficiently advanced to cause them to turn over in their minds the important question of a career.

What we have to warn them against is the danger of having dust thrown in their eyes, by delusive official "explanations," either in the House of Commons in answer to questions, or by memoranda cleverly worded with the intention of misleading civilians who so far interest themselves in the matter as to seek for information either from War Office or Horse Guards officials.

There are, or were, three kinds of rank recognised in the army, namely, substantive, honorary, and relative rank; the last was the recognised rank of army medical officers. It was this that gave them all their privileges and precedence, and, so far as it went, their position in the army. That rank is abolished, and the outcome is they have now no rank at all. Mr Stanhope is, as lawyers say, "instructed" to say that it makes no difference, that the position of army medical officers is not changed, that their privileges remain, and so forth, and we believe that $\mathrm{Mr}$ Stanhope is honest and simple enough to believe what he is told, and, parrot-like, to repeat in the House.

But this is not how the matter is regarded in the army. It may be true a surgeon will get his quarters and his cabin in a transport as he did before, but rank in the army he has none, and so long as this is the case he will be made to feel it every hour of his life. The officers who pay and feed the army have recognised titular rank. They are styled honorary Captains, Majors, Lieut.Colonels, and so on, according to their grade, although it is as notorious as the sun at noonday that they do not run a tenth part of the risks-the honourable risks of war-that the surgeons of the army do from battle injuries and the diseases incident to campaigns. Do our readers doubt this? Let them look at the long list of young surgeons, hardly in their prime, who laid down their lives in our late wars in Afghanistan, in South Africa, in
Egypt, and the Soudan, a list which we place before our readers in another page. We should like to know how many paymasters and commissariat officers lost their lives in battle, or died worn out by the night and day work of field and camp service? Which of them, like Shepherd at Isandlana, when that pitiful massacre was nearly over, dismounted from his horse, in answer to the appeal of a wounded soldier, and, died like a brave man as he was, while binding up the wounds of his humble comrade? Which of them at the miserable fiasco of Engoga went during that long day under fire, as another surgeon did, from one wounded man to another, as calmly as he would have done in the wards of Netley Hospital, and a few days afterwards died of his wounds on Majuba Hill? Not to speak of his noble brother officer, who, when all who were not killed or wounded on that hill-the very name of which brings a blush of shame on every Englishman's face-had left, remained with his wounded, and when about to die from a mortal wound, gathered his remaining energies and fast ebbing strength, and gave a hypodermic injection of morphine to a man screaming under the torture of a wound.

This is a matter that demands plain speaking; and, without any wish to hurt the feelings of any one, we must illustrate our meaning by an example. In the Gazette of Friday, February 25th, an officer is retired with the rank of Major. This meritorious gentleman began his career as a private in the Hospital Corps. The late Professor Parkes took him into his laboratory, as a laboratory assistant, and never rested until he obtained for him the rank of Sergeant; from this he was promoted in the Army Hospital Corps, and, we believe, under some of the many changes of late years, was attached to the Commissariat. On retirement, he carried with him the honorary rank of Major. Mark this: If Dr Parkes had remained in the army, and lived to see the present state of affairs, this Major, in military society, would have been the superior in rank to one of the most illustrious men the medical profession in England has ever produced.

We wish it to be distinctly understood that army medical officers do not covet military titles. What they have a right to demand is, that a Royal Warrant shall be published in which their rank shall be defined, their professional titles being the equivalents of recognised military grades, known and seen of all men-not, as now, the nominal possessors of "privileges" which give them no status that is recognisable. Until this is done, we warn the younger members of our profession that the medical ranks of the army is no longer a place for gentlemen.

(British Medical Fournal 1887;i:843.) 